\section{A Review of Common Liverwort Control Practices in Container Nurseries and Greenhouse Operations}

\author{
Manjot Kaur Sidhu ${ }^{1}$, Roberto G. Lopez ${ }^{1}$, Sushila Chaudhari ${ }^{1}$, \\ and Debalina Saha ${ }^{1}$
}

AdDitional INDEX wORDs. fertilizer placement, herbicides, Marchantia polymorpha, organic mulches, thallus structure, weed competition

Summary. Common liverwort (Marchantia polymorpha) is a primitive, spore-bearing bryophyte that thrives in containerized ornamental crop propagation and production environments. It is one of the major weed problems in container nurseries and greenhouses because it competes with ornamental plants for soil/ growing medium, nutrients, water, space, and oxygen within the container. As a result, its presence can reduce the overall quality and market value of the ornamental crop. Once established in nurseries and greenhouses, it spreads rapidly because of its ability to propagate both asexually and sexually. Currently, no effective methods of controlling common liverwort in container production systems are available because a significant knowledge gap exists. Therefore, research is needed to determine whether organic mulches (types, depths, moisture holding capacity, and particle size), biopesticides, and strategic placement of fertilizers within containers suppress or inhibit common liverwort growth and development. In addition, newer chemicals (both synthetic and organic) and combinations need to be tested on different growth stages of common liverwort. The objective of this review was to summarize previous and current research related to common liverwort control in container production, and to identify areas where additional research is needed either to improve current control methods or to develop new ones.

$\mathrm{T}$ 2013 estimated economic contribution of the ornamental green industry in the United States was $\$ 136$ billion in sales revenue. In terms of employment and gross domestic product (GDP) contributions, the production of nursery, greenhouse, and floriculture crops alone created 240,809 jobs and contributed more than $\$ 20$ billion toward the GDP (Hodges et al., 2015). Weed control is important for

Received for publication 21 May 2020. Accepted for publication 24 June 2020.

Published online 22 July 2020

${ }^{1}$ Department of Horticulture, Michigan State University, 1066 Bogue Street, East Lansing, MI 48824

This work was supported by the U.S. Department of Agriculture National Institute of Food and Agriculture, Hatch project MICL02670 and MICL02472.

We gratefully acknowledge the Michigan Department of Agriculture and Rural Development and the Western Michigan Greenhouse Association for funding.

The use of tradenames in this publication does not imply endorsement by Michigan State University of products named nor criticism of similar ones not mentioned.

D.S. is the corresponding author. E-mail: sahadeb2@ msu.edu.

This is an open access article distributed under the CC BY-NC-ND license (https://creativecommons.org/ licenses/by-nc-nd/4.0/).

https://doi.org/10.21273/HORTTECH04652-20 horticultural crops because weed competition for light, nutrients, water, and space causes reductions in crop growth and yield. In addition, weeds can harbor insects, pests, diseases, and pathogens, resulting in a further reduction of market value of the crops. In restricted growing environments, such as container plant production, weeds reduce marketability and crop growth by as much as $60 \%$ (Fretz, 1972). A single redroot pigweed (Amaranthus retroflexus) or large crabgrass (Digitaria sanguinalis) plant in a 2.4 -L nursery pot reduced japanese holly (Ilex crenata) plant growth by $40 \%$ to $60 \%$ in one season (Fretz, 1972). A large number of eclipta (Eclipta alba) and prostrate spurge (Euphorbia supina) weeds reduced the shoot dry weight of container-grown dwarf indica azalea (Rhododendron eriocarpum) and japanese barberry (Berberis thunbergii) plants (Berchielli-Robertson et al., 1990). Weed control in container nursery production is often the greatest production cost encountered by nursery growers, often exceeding $\$ 4000 /$ acre (Case et al., 2005; Mathers, 2003). Several products registered for use on established ornamentals can be injurious to newly established plants, and hence weed control is a challenge in the production of all nursery plants and is especially problematic in propagation (Fausey, 2003). The large variety of ornamental species in nursery production presents a challenge for herbicide manufacturers because each plant must be tested under different conditions before adding it to a herbicide label (Mervosh and Ahrens, 1998). As a result, growers are often left with limited weed control strategies for ornamentals (Fausey, 2003). There are also few herbicides that are labeled for use inside greenhouses because of their volatility and potential for crop injury. Injury can occur from spray drift if fans are operating at the time of herbicide application or can occur from herbicides that are volatile because vapors can accumulate in enclosed greenhouses and injure the crops (Smith, 2019). According to Norcini et al. (1996), the lowest reported use of herbicides was within greenhouses in comparison with field plantings and nursery container production.

Several difficult-to-control weeds, including higher plants [broadleaves (Dicotyledoneae), grasses (Poaceae), and sedges (Cyperaceae)] as well as primitive plants such as algae (Chlorophyta, Charophyta), liverworts (Marchantiophyta), and mosses (Bryophyta), have spread in nurseries and greenhouses throughout the United States at an alarming rate (Fausey, 2003). And, despite heavy expenditures, crops incur losses of billions of dollars annually (Loux et al., 2019).

\begin{tabular}{llll}
\hline $\begin{array}{l}\text { Units } \\
\begin{array}{l}\text { To convert U.S. to SI, } \\
\text { multiply by }\end{array}\end{array}$ & U.S. unit & SI unit & $\begin{array}{l}\text { To convert SI to U.S., } \\
\text { multiply by }\end{array}$ \\
\hline 0.4047 & acre $(\mathrm{s})$ & $\mathrm{ha}$ & 2.4711 \\
3.7854 & gal & $\mathrm{L}$ & 0.2642 \\
2.54 & inch $(\mathrm{es})$ & $\mathrm{cm}$ & 0.3937 \\
25.4 & inch $(\mathrm{es})$ & $\mathrm{mm}$ & 0.0394 \\
1.1209 & lb/acre & $\mathrm{kg} \cdot \mathrm{ha}^{-1}$ & 0.8922 \\
1 & $\mathrm{ppm}$ & $\mathrm{mg} \cdot \mathrm{L}^{-1}$ & 1 \\
$\left({ }^{\circ} \mathrm{F}-32\right) \div 1.8$ & ${ }^{\circ} \mathrm{F}$ & ${ }^{\circ} \mathrm{C}$ & $\left({ }^{\circ} \mathrm{C} \times 1.8\right)+32$
\end{tabular}


Liverwort is a primitive plant with more than 6000 species occurring naturally in moist, temperate regions throughout the world (Crum, 1991), with common liverwort (Marchantia polymorpha) being the most common in greenhouses and container nurseries (Marble et al., 2017). Common liverwort spreads rapidly in nurseries and greenhouses as a result of its ability to propagate both asexually and sexually (Ross and Puritch, 1981). It is not uncommon for ornamental liners infested with liverwort, such as common liverwort, to be produced in one region of the country, transported to another for finishing, and shipped again to retail (Fausey, 2003). Thus, containers can acquire and disseminate liverwort at each point of transfer. No effective method of controlling common liverwort in container production systems currently exists. Limited research evaluating the effects of fungicides, disinfectants, and insecticides on common liverwort has been published (Chase, 2000; Chase and Osborn 1984; Hammett, 1976). However, varying interpretations of the results have not proved effective for growers (Fausey, 2003). In most cases, application of one product or method is not enough to control common liverwort successfully and may require integration of two or more approaches. The focus of this review is to synthesize previous and current research pertaining to common liverwort control in container nurseries and greenhouses and to discuss and/or identify areas where additional research is needed either to improve existing control methods or to develop new ones.

\section{Morphology of common liverwort}

Liverwort is a nonvascular, primitive, spore-bearing bryophyte that belongs to the Marchantiaceae family (Durand, 1908) and is more closely related to lower group plants such as algae, mosses, and ferns (Polypodiopsida) than to higher group plants (Altland, 2003; Svenson, 1997). This is the second largest phylum of bryophytes as there are 5000 to 7500 species of liverwort all over the world (Soderstrom et al., 2016; Von Konrat et al., 2010). Common liverwort belongs to the thalloid complex of liverworts, which includes about $5 \%$ of all liverworts, and has often been used to represent the model morphology of liverworts (Budke et al., 2018). The thickness of the thallus is 0.3 to $0.6 \mathrm{~mm}$ at the midrib region and gradually becomes thinner toward the margin (Shimamura, 2015). The thallus is dorsiventral with a broad laminar surface for maximum interception of light (Raven et al., 1999). In common liverwort, photosynthesis occurs in a defined cell layer on the dorsal surface (Budke et al., 2018). On the lower surface there are rhizoids and scales, which absorb moisture and anchor the plant body to the substrate (Budke et al., 2018). The rhizoids are in localized areas over the whole ventral surface of the thallus (McConaha, 1941), and they also grow down the grooves in the gametophore stalks (Bell, 1992).

There are two phases in the common liverwort life cycle: sporophytic and gametophytic stages. When common liverwort is exposed to cool temperatures ranging between $10{ }^{\circ} \mathrm{C}$ and $15{ }^{\circ} \mathrm{C}$, the sexual structures or fruiting bodies develop (Newby, 2006), and the sporophytic life cycle begins. During this sporophytic stage, antheridia produced on stalked antheridiophores fertilize the archegonia, which are also borne on stalked archegoniophores to produce spores (Newby, 2006). Common liverwort is a dioecious plant as the male and female gametangia are produced on separate plants (Budke et al., 2018) (Fig. 1). The male gametangia are located on the upper surface of the gametophores whereas the female archegonia are inverted and hang downward (Budke et al., 2018). Irrigation or rainwater mainly facilitate sperm dispersal, although no studies have been conducted to determine whether animals or insects may contribute to their dispersal (Budke et al., 2018). The archegonia are fertilized by antheridia to produce sporangia. Each sporangium then gives rise to a spore mother cell that produces four tetrahedral spores (Durand, 1908).

Spores germinate to give rise to the gametophytic life cycle. Spore germination depends on light (Heald, 1898) and requires daylengths of $10 \mathrm{~h}$ or longer (Nakazato et al., 1999). During the gametophytic life cycle, the plant propagates asexually by producing gemmae within cup-like structures called gemmae cups (Newby, 2006) (Fig. 2).
Numerous gemmae, produced by each gemmae cup, are released to the immediate surroundings when they come in contact with irrigation or rainwater (Svenson, 1997). A single gemma can give rise to one or two clonal plants after contact with moist soil or media (Saha et al., 2020). Fragmentation is another method of asexual propagation in common liverwort (Svenson, 1997). The common liverwort sporophytes are dependent on the gametophytes for water and nutrition. Each sporophytic structure is composed of a foot (which is embedded in the female gametophyte), a seta, and a capsule (Shimamura, 2015). The capsules contain diploid elaters that are intermixed with the haploid spores (England, 2007). Elaters provide nutrition for the new, developing spores; facilitate response to

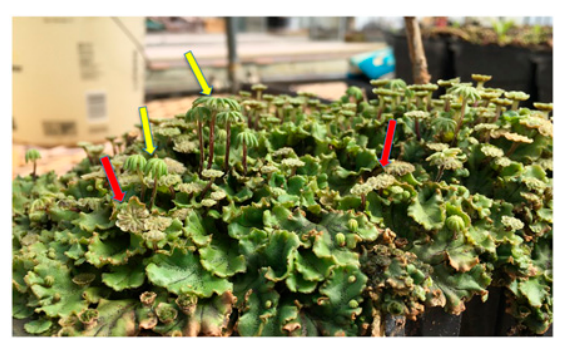

Fig. 1. Male antheridia (red arrows) on stalked antheridiophores and umbrella-like female archegonia (yellow arrows) on stalked archegoniophores on separate thalli of common liverwort under greenhouse conditions.

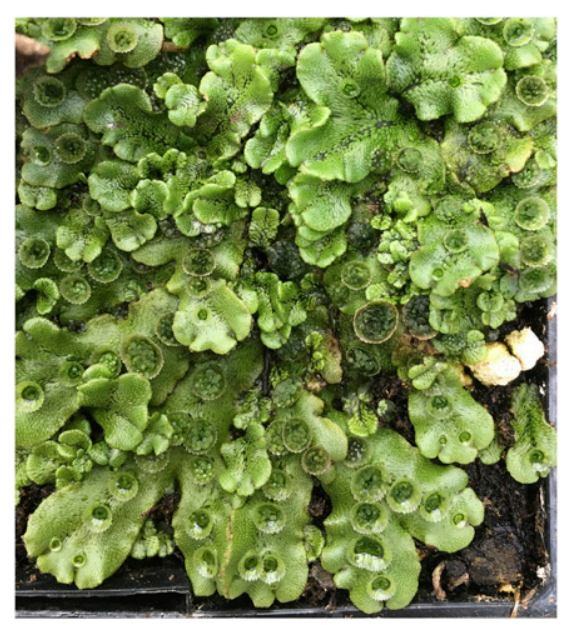

Fig. 2. Gametophytic life cycle of common liverwort is represented by circular gemma cups containing numerous gemmae. 
changing moisture and humidity; and help in spore dispersal (Kremer and Drinnan, 2003; Schuster, 1966).

\section{Common liverwort as a major weed in container nurseries and greenhouses}

Historically common liverwort was reported as a weed in cooler regions of the Northeast and Pacific Northwest regions of the United States (Newby, 2006). However, common liverwort is one of the major weeds in container nurseries and greenhouse operations nationwide because it competes with the ornamental plant for soil/growing medium, nutrients, water, space, and oxygen within the container (Fig. $3)$. Vegetative growth occurs most rapidly at temperatures between 18 and $22{ }^{\circ} \mathrm{C}$ (O'Hanlon, 1926) and thus thrives in propagation and container production environments that have low ultraviolet radiation, high humidity and/or soil moisture, and high fertility (Newby et al., 2006). In container plant production, common liverwort infestations use nutrients and water intended for the crop, impede water movement into the root zone, and reduce crop market value (Svenson, 1997) and overall quality of the ornamental. Therefore, controlling common liverwort in nursery and greenhouse container ornamental production is extremely important.

Common liverwort can form a thick mat, covering not only the container media surfaces (Altland et al., 2007), but also covering walkways and

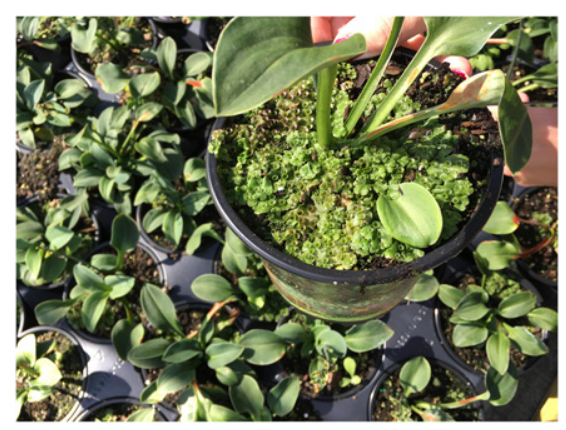

Fig. 3. Common liverwort formed a mat and grew in the container media inside a greenhouse operation. It is competing with the ornamental plant for media, water, nutrients, space, and oxygen, and is reducing the overall quality of the ornamental crop. poorly drained areas under greenhouse benches and on nursery groundcover, especially in the presence of overhead irrigation. Competition from weeds can limit the root volume of containerized crops. Similar to other weeds, common liverwort can provide a habitat for pests and potential pathogens such as fungus gnats (e.g., Bradysia sp.), snails (e.g., Helix sp.), slugs (e.g., Deroceras sp.), and a host of microbial threats such as basal rot (Fusarium oxysporum) and damping-off (Pythium aphanidermatum) (Svenson, 1997). Additional costs to control these pests, combined with production losses resulting from their activity, can reduce profit margins.

The main limitation for common liverwort control inside the greenhouse is the lack of herbicide options because most are not labeled for greenhouse use. On the other hand, in nursery container production, herbicides used at greater rates needed for common liverwort control can cause phytotoxicity to sensitive ornamental plants and can have residual effects as well. Hand-removal of common liverwort is very laborious, timeconsuming, and costly because liverwort forms a mat-like structure on top of the container medium. To remove the rhizoids, $\approx 1$ inch of the media needs to be removed from the container and the medium must be subsequently replaced. Currently, flumioxazin is one of the synthetic herbicides that has been labeled for common liverwort control and is popular among commercial growers. However, flumioxazin and other potential organic and synthetic herbicides have not been tested on different common liverwort growth stages. The efficacy of these chemicals may vary according to different growth stages of common liverwort.

\section{Overview of nonchemical control of common liverwort}

Organic MULChing. In general, top-dressing with organic mulches such as pine (Pinus sp.) bark, pine straw, and hardwood mulch reduces weed growth in nursery container production (Llewellyn et al., 2003; Saha et al., 2019a). Saha et al. (2019a) quantified the effect of herbicide combinations with pine bark, pine straw, and hardwood chip mulches on weed control for container production. They reported an $88 \%$ to $100 \%$ reduction of large crabgrass and garden spurge (Euphorbia birta) in containers with a combination of herbicide and mulch with depths of 1 inch or greater. According to Svenson (1997), fast-drying mulches such as hazelnut [european hazelnut (Corylus avellana)] shells, rice (Oryza sativa) hulls, and pumice on the container media surface can suppress common liverwort growth to some extent. Altland and Krause (2014) reported that top-dressing containers in the greenhouse with rice hull mulch can reduce common liverwort growth. Rice hulls applied at a depth of $0.6 \mathrm{~cm}$ showed $2.5 \%$ and $20 \%$ common liverwort coverage at 4 and 8 weeks after potting (WAP), respectively. In contrast, rice hulls at depths of 1.3 and $2.5 \mathrm{~cm}$ showed $0 \%$ common liverwort coverage at 4 and 8 WAP. However, no research has been conducted to determine how different organic mulch types, depths, particle sizes, and their moistureholding capacity can impact common liverwort growth in nursery containers and in greenhouses.

Fertilization PRACTICes. Common liverwort growth is correlated with increasing nitrogen levels (Svenson, 1998). Nitrogen application rates less than 75 ppm slow down common liverwort establishment (Svenson, 1997). However, nitrogen less than $75 \mathrm{ppm}$ is usually not sufficient for growing ornamental crops. For example, poinsettia $(E u-$ phorbia pulcherrima), bedding plants, and geraniums (Geranium sp.) require 250,200 , and 250 ppm nitrogen, respectively, for optimal growth (Cox, 1997), whereas some commercial growers often deliver 125 to 150 ppm of nitrogen to bedding plants and geraniums. By altering the placement of controlled-release fertilizers (CRFs) within containers, growth of traditional weeds can be decreased. For example, incorporation of CRFs in the substrate increased spotted spurge (Euphorbia maculata) germination by $77 \%$ to $183 \%$ compared with top-dressing, subdressing, dibbling, and no fertilizer (Saha et al., $2019 b$ ). Subdressed CRFs were placed at a depth of $7.6 \mathrm{~cm}$ below the surface of the media as a layer, whereas dibbled CRFs were placed in a small pocket at a depth of $7.6 \mathrm{~cm}$ below the surface of the media. Both 
subdressing and dibbling reduced seed production by $63 \%$ and $92 \%$ for large crabgrass and spotted spurge, respectively (Saha et al., 2019b). Strategic placement of CRFs can increase nutrient availability to the crop, but not to the smaller weed seeds that are introduced at the top layer. This method has been effective in controlling general broadleaf and grass weed species such as eclipta (Eclipta prostrata), spotted spurge, and large crabgrass. Altland (2004) recommended incorporating or dibbling CRFs as a method to reduce common liverwort growth compared with topdressing. However, additional research is required to determine whether CRF placement and depths in the container can control common liverwort and not negatively influence crop growth and whether it requires more labor than the popular topdressing method.

IRRIGATION PRACTICES. Given that common liverwort growth is promoted by moist conditions, containerized crops should be irrigated according to soil moisture content instead of following fixed irrigation schedules and rates (Altland, 2004). In addition, air circulation should be improved around the container surface to decrease localized relative humidity (Altland, 2004). Overhead irrigation can cause more splashing of water and increase dispersal of the gemmae than drip or flood floor irrigation systems. In a study conducted by Svenson (1998), a high irrigation frequency resulted in a $100 \%$ common liverwort coverage on the container media, whereas only $59 \%$ of common liverwort coverage was observed with a low irrigation frequency. Therefore, cultural practices that reduce the moisture content of the container media can help reduce common liverwort growth (Newby, 2006). Svenson and Deuel (2000) found increased common liverwort coverage in containers with daily irrigation compared with low (every $3 \mathrm{~d}$ ) irrigation across a range of surface mulch treatments that included hazelnut shells, oyster shells, and copper-treated geotextile disks. They also recommended the use of subirrigation instead of overhead irrigation to reduce common liverwort growth. Clemens et al. (1991) compared different irrigation methods including capillary, ebb-and-flow, and overhead, and reported that a greater common liverwort presence on the compost surface was the main problem with capillary systems.

EFFECTS OF LIGHT AND SHADING. Light has significant effects on common liverwort growth and reproduction. It has been observed that light intensities of 370 to $555 \mu \mathrm{mol} \cdot \mathrm{m}^{-2} \cdot \mathrm{s}^{-1}$ promote vegetative growth of common liverwort whereas greater light intensities inhibit it (Mache and Loiseaux, 1973). More gemma cups (asexual structures) are produced under a short photoperiod of about $8 \mathrm{~h}$ than under a long photoperiod of 17 to $18 \mathrm{~h}$ (Voth and Hamner, 1940). High light intensity, long days, and natural diffused daylight can accelerate female sexual structure, archegoniophore formation (Terui, 1981). Even spore germination is light dependent (Heald, 1898) and requires light for $10 \mathrm{~h}$ or longer (Nakazato et al., 1999). De Greef et al. (1971) reported that senescence in common liverwort is also controlled by phytochrome and photoperiods of white light. The green tissue of mature common liverwort gets bleached significantly when placed in continuous darkness for $4 \mathrm{~d}$, but remained green when given daily $\mathrm{l}$-h photoperiods of white light (De Greef et al., 1971). The bleaching was taken as a measure of senescence because a breakdown of cell organelles and cytoplasm accompanies loss of chlorophyll in the bleached tissue (De Greef et al., 1971). So, from vegetative growth, formation of reproductive structures, to senescence, most of the phases in the common liverwort life cycle are affected by either light quality or quantity. Inside greenhouses, ornamental crop canopies can produce enough shade on the container media surface to promote common liverwort growth (Svenson et al., 2001). Altland and Krause (2014) quantified how the canopy of containerized 'Radrazz' rose (Rosa sp.) influenced common liverwort growth. Under a rose canopy, there was $13 \%, 40 \%$, and $99 \%$ common liverwort coverage of the container surface at 1,4 , and 8 WAP. In contrast, there was only $6 \%$, $21 \%$, and $48 \%$ common liverwort coverage on container media at 1,4 , and 8 WAP in the absence of canopy shading. This research provides evidence that canopy shading can increase common liverwort growth in comparison with no shading. Because very little research has been conducted on the effects of shading on common liverwort growth and development, more research is required in this area.

\section{Overview of chemical control of common liverwort}

Chemical control of common liverwort by preemergence herbicides was suggested in 1979 (Elmore et al., 1979). Benzalkonium chloride and cinnamic aldehyde (Cinnacure; ProGuard, Suisun City, CA) have shown some success in controlling common liverwort; however, these products can sometimes injure ornamental crops, depending on the season (Svenson, 1997). Herbicides containing flumioxazin, oxadiazon, or oxyfluorfen are effective for preemergence control of common liverwort (Fausey, 2003; Svenson, 1998). Fausey (2003) reported that under controlled environment conditions, common liverwort can be managed to some extent with flumioxazin, oxyfluorfen, acetic acid, pelargonic acid, and oxadiazon. In addition to postemergence control of common liverwort, flumioxazin, oxadiazon, and oxyfluorfen also had residual activity when applied to potting media. In comparison of granular and sprayable formulations of flumioxazin, oxadiazon, and oxyfluorfen, the control of established common liverwort was greater with sprayable formulations than with granular ones. The granular and sprayable formulations of flumioxazin provided greater pre- and postemergence control of common liverwort compared with granular or sprayable formulations of oxadiazon and oxyfluorfen. All three of these herbicides are known as "protox" or protoporphyrinogen oxidase (PPO) inhibitors and belong to the Weed Science Society of America (WSSA) Group 14 herbicides. According to Marble et al. (2017), preemergence herbicides of WSSA Group 14 may provide some level of common liverwort suppression, depending on nursery conditions, but further research is required.

Stamps and Chandler (2004) reported that a granular form of sodium carbonate peroxyhydrate (TerraCyte; BioSafe Systems, East Hartford, CT) can provide excellent postemergence common liverwort control after 
2 weeks of treatment. However, Altland et al. (2003) reported poor to moderate control of common liverwort with sodium carbonate peroxyhydrate applied at a rate of 728.5 $\mathrm{kg} \cdot \mathrm{ha}^{-1}$, and it was injurious to certain perennial crops. Although some synthetic herbicides have been tested to control common liverwort, many of these products are phytotoxic to ornamental plants. A list of synthetic herbicides/chemicals that have shown some degree of common liverwort control are provided in Table 1.

Herbicide efficacy can vary from region to region or depends on environmental factors and weed species population (Varanasi et al., 2016; Waltz et al., 2004). For example, glyphosate efficacy can vary on broadleaf weeds such as velvetleaf (Abutilon theophrasti) with application time of day (Waltz et al., 2004). Velvetleaf control was consistently greater with glyphosate applications during the day compared with at night, regardless of constant air temperature and relative humidity, dew absence or presence, or leaf blade orientation with natural light/dark movements or a fixed horizontal position (Waltz et al., 2004). In a series of experiments, Newby et al. (2007) showed that granular preemergence herbicide efficacy on common liverwort control varied by location. Flumioxazin and oxadiazon provided the most effective control in Alabama, whereas flumioxazin and oxyfluorfen + oryzalin provided the most effective preemergent common liverwort control in Oregon. This variation in herbicide efficacy for common liverwort control as reported by Newby et al. (2007) might be a result of different environmental conditions/cultural practices in two different locations. More indepth research is required to determine the underlying causes for such variation in herbicide efficacy for common liverwort control.

Another chemical, quinoclamine (Gentry; Chemtura Corp., Middlebury, CT) has shown $96 \%$ postemergence control at $2 \mathrm{~d}$ after treatment (DAT) and $94 \%$ control at 45 DAT to mature common liverwort (Altland et al., 2003). Altland et al. (2008) also studied the response of common liverwort to the herbicide quinoclamine in a medium containing pine bark. Quinoclamine provided preemergent control of gemmae propagules as well as contributed to postemergent control of established common liverwort. In a simulation of preemergent activity of the herbicide, hydroponically grown common liverwort and germinating gemmae were subjected to increasing concentrations of quinoclamine. Phytotoxicity to both gemmae and plants was obtained with a minimal herbicide concentration of 4 to $6 \mathrm{mg} \cdot \mathrm{L}^{-1}$. In a later study, Altland et al. (2011) studied the differential response of common liverwort tissues to postapplied quinoclamine. The archegonial receptacles (female) were more tolerant of quinoclamine than either antheridial receptacles (male) or thalli (leaflike structures). The doses that resulted in $50 \%$ control of the population $\left(I_{50}\right)$ of antheridial receptacles and juvenile thalli were 1.60 and $1.27 \mathrm{~kg} \cdot \mathrm{ha}^{-1}$, respectively. The $I_{50}$ of archegonial receptacles exceeded $10.45 \mathrm{~kg} \cdot \mathrm{ha}^{-1}$. After application of radiolabeled quinoclamine, absorption of the carbon-14 isotope was less in archegonial receptacles than in either antheridial receptacles or thalli. The tolerance of archegonial receptacles to quinoclamine could be attributed in part to reduced absorption, which happened as a result of limited pore size and lesser pore area of the archegonial receptacles.

Khadduri (2011) reported the effect of essential oils or distilled plant extracts in common liverwort control in container nursery production during three seasons of trials. Sporatec [Brandt Consolidated, Springfield, IL (formerly sold as Sporan; EcoSMART Technologies, Franklin, TN)] is a product that consists of rosemary (Rosmarinus sp.), clove (Syzygium aromaticum), and thyme [common thyme (Thymus vulgaris)] oil. This product was tested on a common liverwort and moss-infested crop of western redcedar (Thuja plicata) seedlings (Khadduri, 2011). The results from this trial showed $91 \%$ common liverwort control 9 DAT. However, there was significant damage to the redcedar plants, and the common liverwort reestablished within $14 \mathrm{~d}$ of knockdown. Other organic products such as pelargonic acid, acetic acid products, d-limonene, and ammonium nonanoate have shown some suppression of common liverwort, but these compounds often require repeated application and can cause severe damage to ornamentals crops (Table 2).
Graham and Dixon (2012) reported that the maintenance of a small residual aqueous ozone concentration during the distribution of irrigation water to the crop has the potential to offer some level of common liverwort control. They conducted experiments to evaluate contact time thresholds and application frequencies suitable for common liverwort management. Contact times between 0.84 and 1.68 $\mathrm{mg} \cdot \mathrm{L}^{-1}$ per min with three applications per week reduced common liverwort growth and fecundity. Chemical treatments that are commonly used to reduce spore loads of common liverwort, moss, and algae are quaternary ammonium chlorides, sold as products such as GreenShield (Whitmire Micro-Gen Research Laboratories, St. Louis, MO), Physan 20 (Maril Products, Tustin, $\mathrm{CA}$ ), and Triathlon (OHP, Mainland, $\mathrm{PA})$. Other chemicals include hydrogen peroxide (ZeroTol; BioSafe Systems, Hartford, CT) and chlorine bleach, which are used as disinfectants for controlling algae, common liverwort, and moss (Smith, 2007). These disinfectant chemicals are mostly suitable for noncrop targets. If they come in contact with the sensitive ornamental plants, severe injury can occur.

\section{Knowledge gaps and future research areas}

Although initial research has been conducted with mulch materials such as rice hull and hazelnut shells, more research is required to determine which type of organic mulch material can provide acceptable common liverwort control. Impacts of mulch depth, particle size, aging, and moisture holding capacity of various organic mulch materials need to be investigated. Based on such data, recommendations specific to both nursery and greenhouse operators for controlling common liverwort can be made. Organic mulch extracts with allelopathic properties can be used for weed management because they can act as natural herbicides or biopesticides (Saha et al., 2018). These natural products possess complex structures, can decompose readily, and contain different modes of action compared with synthetic herbicides (Dayan et al., 1999; Duke et al., 1997, 2000). Hence, these natural chemicals can act as alternatives to synthetic herbicides for controlling weeds in case of herbicide-sensitive ornamentals 
Table 1. Synthetic herbicides/chemicals evaluated for common liverwort control.

\begin{tabular}{|c|c|c|c|}
\hline Active ingredient & Tradename & $\begin{array}{c}\text { Greenhouses and } \\
\text { other enclosed structures }\end{array}$ & Notes \\
\hline Diquat & $\begin{array}{l}\text { Reward (Syngenta } \\
\text { Crop Protection, } \\
\text { Greensboro, NC) }\end{array}$ & No & $\begin{array}{l}\text { Has shown postemergence control } \\
\text { of common liverwort but requires } \\
\text { repeated application with surfactant } \\
\text { (Marble et al., 2017). }\end{array}$ \\
\hline \multirow[t]{2}{*}{ Flumioxazin } & $\begin{array}{l}\text { BroadStar (Valent } \\
\text { USA, Walnut Creek, CA) }\end{array}$ & No & $\begin{array}{l}\text { BroadStar can be applied to container } \\
\text { production and is less effective than the } \\
\text { sprayable formulation (SureGuard). }\end{array}$ \\
\hline & SureGuard (Valent USA) & $\begin{array}{c}\text { Yes (only inside } \\
\text { empty greenhouse) }\end{array}$ & $\begin{array}{l}\text { SureGuard has shown both pre- and } \\
\text { postemergence control of common } \\
\text { liverwort (Marble et al., 2017). }\end{array}$ \\
\hline Oxadiazon + prodiamine & $\begin{array}{l}\text { RegalStar II (Regal } \\
\text { Chemical Co., } \\
\text { Alpharetta, GA) }\end{array}$ & No & $\begin{array}{l}\text { Has shown some preemergence } \\
\text { common liverwort control and can } \\
\text { be used in container production in } \\
\text { nurseries (Marble et al., 2017). }\end{array}$ \\
\hline $\begin{array}{l}\text { Oxyfluorfen + } \\
\text { oryzalin }\end{array}$ & $\begin{array}{l}\text { Rout (ICL Specialty } \\
\text { Fertilizers, Summerville, } \\
\text { SC) }\end{array}$ & No & $\begin{array}{l}\text { Can be used in container production } \\
\text { only. Has shown preemergent common } \\
\text { liverwort control, but effect varies from } \\
\text { region to region, depending on } \\
\text { environmental conditions } \\
\text { (Newby et al., 2007). }\end{array}$ \\
\hline $\begin{array}{l}\text { Oxyfluorfen + } \\
\text { prodiamine }\end{array}$ & $\begin{array}{l}\text { Biathlon (OHP, } \\
\text { Mainland, PA) }\end{array}$ & No & $\begin{array}{l}\text { Labeled for use in ornamental plant } \\
\text { production in containers and has } \\
\text { shown suppression of common } \\
\text { liverwort (Marble et al., 2017). }\end{array}$ \\
\hline $\begin{array}{l}\text { Quaternary } \\
\text { ammonium } \\
\text { chloride }\end{array}$ & $\begin{array}{l}\text { GreenShield (Whitmire } \\
\text { Micro-Gen Research } \\
\text { Laboratories, St Louis, } \\
\text { MO); Physan } 20 \\
\text { (Maril Products, } \\
\text { Tustin, CA); Triathlon } \\
\text { (OHP) }\end{array}$ & Yes (only on hard surfaces) & $\begin{array}{l}\text { These products are disinfectants and } \\
\text { can be used in nurseries and to } \\
\text { control common liverwort, algae, } \\
\text { and moss. Contact with sensitive ornamental } \\
\text { plants can cause severe injuries. }\end{array}$ \\
\hline $\begin{array}{l}\text { Sodium carbonate } \\
\text { peroxyhydrate }\end{array}$ & $\begin{array}{l}\text { TerraCyte (BioSafe } \\
\text { Systems, East Hartford, CT) }\end{array}$ & Yes & $\begin{array}{l}\text { Can be used in container production } \\
\text { (Saha et al., 2020) and suppresses } \\
\text { mature common liverwort } \\
\text { (Altland et al., 2003). However, it can } \\
\text { cause severe injury to certain perennial } \\
\text { plants if granules become trapped in or } \\
\text { on plant foliage (Altland et al., 2003; } \\
\text { Marble et al., 2017). }\end{array}$ \\
\hline
\end{tabular}

(Marble, 2015). To our knowledge, no research has been published on how different mulch extracts with allelopathic properties can control common liverwort in greenhouse and nursery container production. Because there is a limitation to using synthetic herbicides within greenhouses and inside closed structures, these natural products (organic mulch extracts) may act as potential biopesticides for common liverwort control. 
Table 2. Organic herbicides/chemicals evaluated for common liverwort control.

\begin{tabular}{|c|c|c|c|}
\hline Active ingredient & Tradename & $\begin{array}{c}\text { Greenhouses and } \\
\text { other enclosed structures }\end{array}$ & Notes \\
\hline $\begin{array}{l}\text { Combination of } \\
\text { rosemary, clove, } \\
\text { and thyme oil }\end{array}$ & $\begin{array}{l}\text { Sporatec (Brandt } \\
\text { Consolidated, } \\
\text { Springfield, IL) }\end{array}$ & Yes & $\begin{array}{l}\text { Sort-term postemergence control } \\
(90 \%) \text { but common liverwort } \\
\text { reestablished within } 2 \text { weeks } \\
\text { (Khadduri, 2011). }\end{array}$ \\
\hline Pelargonic acid & $\begin{array}{l}\text { Scythe (Gowan Co., } \\
\text { Yuma, AZ) }\end{array}$ & $\mathrm{Yes}^{\mathrm{z}}$ & $\begin{array}{l}\text { Requires repeated applications } \\
\text { for effective control of common } \\
\text { liverwort (Marble et al., 2017). }\end{array}$ \\
\hline Cinnamic aldehyde & $\begin{array}{l}\text { Cinnacure (Pro- } \\
\text { Guard, Suisun City, CA) }\end{array}$ & Yes & $\begin{array}{l}\text { Acts as contact herbicide and has } \\
\text { shown some suppression of common } \\
\text { liverwort, but may cause sporadic injury } \\
\text { to ornamental crops, depending on } \\
\text { the environmental conditions (Svenson, 1997) }\end{array}$ \\
\hline $\begin{array}{l}\text { Ammonium } \\
\text { nonanoate }\end{array}$ & $\begin{array}{l}\text { Axxe (BioSafe Systems, } \\
\text { East Hartford, CT) }\end{array}$ & $\mathrm{Yes}^{\mathrm{z}}$ & $\begin{array}{l}\text { Broad-spectrum herbicide that requires } \\
\text { repeated application for effective } \\
\text { postemergence control of common } \\
\text { liverwort. Can be used in nursery container } \\
\text { production (Marble et al., 2017). }\end{array}$ \\
\hline d-Limonene & $\begin{array}{l}\text { AvengerAg (Avenger } \\
\text { Organics, Gainesville, GA) }\end{array}$ & $\mathrm{Yes}^{\mathrm{z}}$ & $\begin{array}{l}\text { Nonselective contact herbicide that may } \\
\text { require repeated application for effective } \\
\text { postemergence control of common } \\
\text { liverwort. Can be used in nursery container } \\
\text { production (Marble et al., 2017). }\end{array}$ \\
\hline
\end{tabular}

${ }^{\mathrm{z}}$ May cause damage to ornamentals if applied directly. Spot application is suggested.

Altland (2004) made a recommendation of incorporating or dibbling CRFs at a depth of $7.6 \mathrm{~cm}$ to reduce common liverwort growth. However, there is no research report or data available on strategic placement of fertilizer in the container that can control common liverwort effectively. Research is required to determine whether subdressing or dibbling of CRF can be an effective method of suppressing common liverwort growth in comparison to popular practices of top-dressing and incorporation. The right depths for subdressing and dibbling need to be determined. In addition, further studies need to focus on how fertilizer placement can impact common liverwort growth rate and reproduction cycles, and influence competitiveness with ornamental crops.

Some attempts have been made previously to control common liverwort with both synthetic and organic chemicals/herbicides, but more research is required in this area because, in many cases, the results varied from region to region and with environmental conditions. Research needs to focus on how different synthetic and organic chemicals can affect different growth stages of common liverwort (sexual structures and vegetative body), and how different combinations of newer herbicides (preemergence and postemergence activity) at different application rates can affect common liverwort growth. In particular, different combinations of preemergence herbicides containing active ingredients of PPO inhibitors need to be tested on common liverwort growth stages. Dimethenamid$\mathrm{P}$ is another herbicide that potentially suppresses common liverwort and requires an in-depth study (Marble et al., 2017). Identifying the group of chemicals and determining their phytotoxic effects on ornamentals, costs involved in their application, and application rates and timing that can provide control of common liverwort will help the billion-dollar green industry in the United States to improve productivity and profit margins. Hence, there is a need to conduct further research on both nonchemical and chemical methods for controlling common liverwort in container nurseries and greenhouse operations.

\section{Literature cited}

Altland, J. 2003. Weed control in container crops: A guide to effective weed management through preventive measures. Oregon State Univ. Ext. Serv EM 8823. 10 Apr. 2020. <https:// oregonstate.edu/dept/nursery-weeds / feature_articles/EM8823>

Altland, J. 2004. Common weeds in Oregon container crops. Oregon State Univ. Ext. Serv. EM 8874. 10 Apr. 2020. $<$ https://catalog.extension.oregonstate. edu/sites/catalog/files/project/pdf/ em8874.pdf>.

Altland, J. and C. Krause. 2014. Parboiled rice hull mulch in containers reduces liverwort and flexuous bittercress growth. J. Environ. Hort. 32:59-63.

Altland, J., R. Regan, and A. Newby. 2003. Liverwort control in propagation: Challenges and opportunities. Comb. Proc. Intl. Plant Prop. Soc. 53:383-386.

Altland, J., G. Wehtje, C.H. Gilliam, and M.E. Miller. 2007. Liverwort (Marchantia polymorpha) control with quinoclamine. Weed Technol. 21:483-488. 
Altland, J., G. Wehtje, M. Mckee, and C. Gilliam. 2008. Liverwort (Marchantia polymorpha) response to quinoclamine in pine bark substrate. Weed Sci. 56:762766.

Altland, J., G. Wehtje, J. Sibley, M. Miller, C. Gilliam, and C. Krause. 2011. Differential response of liverwort (Marchantia polymorpha) tissue to post-applied quinoclamine. Weed Technol. 25:580-585.

Bell, P.R. 1992. Green plants: Their origin and diversity. Cambridge University Press, Cambridge, UK.

Berchielli-Robertson, D.L., C.H. Gilliam, and D.C. Fare. 1990. Competitive effects of weeds on the growth of container grown plants. HortScience 25:77-79.

Budke, J.M., E.C. Bernard, D.J. Gray, S. Huttunen, B. Piechulla, and R.N. Trigiano. 2018. Introduction to the special issue on bryophytes. Crit. Rev. Plant Sci. 37:102112.

Case, L.T., H.M. Mathers, and A.F. Senesac. 2005. A review of weed control practices in container nurseries. Weed Technol. 15:535-545.

Chase, A.R. 2000. The slippery plant pests: Algae, moss, and liverwort. Greenhouse Product News 10(10):60-63. 10 Apr. 2020. <https://gpnmag.com/article/slipperyplant-pests-algae-moss-and-liverwort $/>$.

Chase, A.R. and L.S. Osborne. 1984. Controlling algae in foliage plant production. Proc. Florida State Hort. Soc. 97:274-278.

Clemens, J., B.C. Christie, and C.J. Barnaby. 1991. Watering container plants five different ways. Comb. Proc. Intl. Plant Prop. Soc. 41:98-102.

Cox, D. 1997. Basic fertilizer programs for containerized greenhouse crops. 10 Apr. 2020. $<$ https://ag.umass.edu/greenhousefloriculture/fact-sheets/basic-fertilizer-programsfor-containerized-greenhouse-crops $>$.

Crum, H.A. 1991. Liverworts and hornworts of southern Michigan. University of Michigan Herbarium, Ann Arbor, MI.

Dayan, F., J. Romagni, M. Tellez, A. Rimando, and S. Duke. 1999. Managing weeds with natural products. Pestic. Outlook 10:185-188.

De Greef, J., W.L. Butler, T.F. Roth, and H. Fredericq. 1971. Control of senescence in Marchantia by phytochrome. Plant Physiol. 48:407-412.

Duke, S.O., F.E. Dayan, A. Hernandez, M.V. Duke, and H.K. Abbas. 1997. Natural products as leads for new herbicide modes of action. Proc. Brighton Crop Protection Conf. 2:579-586.
Duke, S.O., J.G. Romagni, and F.E. Dayan. 2000. Natural products as sources for new mechanisms of herbicidal action. Crop Prot. 19:583-589.

Durand, E.J. 1908. The development of sexual organs and sporogonium of Marchantia polymorpha. Bull. Torrey Bot. Club 35:321-335.

Elmore, C.L., W.A. Humphrey, and K.A. Hesketh. 1979. Container nursery weed control. Univ. California Coop. Ext. Publ. Lflt. 21059.

England, J.E. 2007. The biology, epidemiology and control of liverwort infestation of nursery plant containers. PhD Diss., Imperial College London, London, UK.

Fausey, J.C. 2003. Controlling liverwort and moss now and in the future. HortTechnology 13:35-38.

Fretz, T.A. 1972. Weed competition in container grown japanese holly. HortScience 7:485-486.

Graham, T. and M.A. Dixon. 2012. Liverwort control: An ancillary role for ozone-based irrigation water treatment systems? HortScience 47:361-367.

Hammett, K.R. 1976. Control of liverwort growth on the surface of soil in plant containers. N. Z. J. Exp. Agr. 4:117-119.

Heald, F.D.F. 1898. Conditions for germination of spores of bryophytes and pteridophytes. Bot. Gaz. 26:25-45.

Hodges, A.W., C.R. Hall, M.A. Palma, and H. Khachatryan. 2015. Economic contributions of the green industry in the United States in 2013. HortTechnology 25:805-814.

Khadduri, N. 2011. Using essential oils to control moss and liverwort in containers. U.S. Dept. Agr. For. Serv. Proc. RMRSP-65. p. 133-138.

Kremer, C. and A. Drinnan. 2003. Secondary wall formation in elaters of liverworts and the hornwort Megaceros. Intl. J. Plant Sci. 164:823-834.

Llewellyn, J., K. Osborne, C. SteerGeorge, and J. West. 2003. Commercially available organic mulches as weed barrier for container production. Comb. Proc. Intl. Plant Prop. Soc. 53:590-593.

Loux, M.M., D. Doohan, A.F. Dobbels, B. Reeb, W.G. Johnson, B.G. Young, J. Ikley, and A. Hager. 2019. 2019 Weed control guide for Ohio, Indiana and Illinois. Ohio State Univ. Ext. WS16, Bul. 789, ILl5.

Mache, R. and S. Loiseaux. 1973. Light saturation of growth and photosynthesis of the shade plant Marchantia polymorpha. J. Cell Sci. 12:391-401.

Marble, S.C. 2015. Herbicide and mulch interactions: A review of the literature and implications for the landscape maintenance industry. Weed Technol. 29:341349.

Marble, C., M.S. Frank, D. Laughinghouse, S. Steed, and N. Boyd. 2017. Biology and management of liverwort (Marchantia polymorpha) in ornamental crop production. Univ. Florida, Inst. Food Agr. Sci. ENH278.

Mathers, H.M. 2003. Novel methods of weed control in containers. HortTechnology 3:28-34.

McConaha, M. 1941. Ventral structures effecting capillarity in the Marchantiales. Amer. J. Bot. 28:301-306.

Mervosh, T.L. and J.F. Ahrens. 1998. Preemergence herbicides for containergrown perennials. Proc. Northeastern Weed Sci. Soc. 52:131.

Nakazato, T., A. Kadota, and M. Wada. 1999. Photoinduction of spore germination in Marchantia polymorpha L. is mediated by photosynthesis. Plant Cell Physiol. 40:1014-1020.

Newby, A. 2006. Liverwort control in container-grown nursery crops. MS Thesis, Auburn University, Auburn, AL. 10 Apr. 2020. <https://etd.auburn.edu/bitstream/ handle/10415/300/NEWBY_ADAM_48. pdf $>$.

Newby, A., J.E. Altland, C.H. Gilliam, and G. Wehtje. 2006. Postemergence liverwort control in container-grown nursery crops. J. Environ. Hort. 24:230-236.

Newby, A., J.E. Altland, C.H. Gilliam, and G. Wehtje. 2007. Pre-emergence liverwort control in nursery containers. HortTechnology 17:496-500.

Norcini, J.G., M.P. Garber, W.G. Hudson, R.K. Jones, A.R. Chase, and K. Bondari. 1996. Pest management in the United States greenhouse and nursery industry: IV. Weed control. HortTechnology 6:211-216.

O'Hanlon, M.E. 1926. Germination of spores and early stages in development of gametophyte of Marchantia polymorpha. Bot. Gaz. 82:215-222.

Raven, P.H., R.F. Evert, and S.E. Eichorn. 1999. Biology of plants. Freeman, New York, NY.

Ross, R.L.M. and G.S. Puritch. 1981. Identification, abundance, and origin of moss, liverwort, and algal contaminants in greenhouses of containerized forest nurseries. Can. J. For. Res. 11:356-360. 
Saha, D., H. Lindberg, and M.K. Sidhu. 2020. Identifying and managing liverwort in Michigan nurseries and greenhouses. 10 Apr. 2020. <https://www.canr.msu.edu/floriculture/ uploads/files/LiverwortFactSheet.pdf $>$.

Saha, D., S.C. Marble, and B.J. Pearson. 2018. Allelopathic effects of common landscape and nursery mulch materials on weed control. Front. Plant Sci. 9:1-8.

Saha, D., C. Marble, B.J. Pearson, H.E. Perez, G.E. MacDonald, and D.C. Odero. 2019a. Influence of mulch type and depth, herbicide formulation, and post-application irrigation volume on control of common landscape weed species. Hort Technology 29:65-77.

Saha, D., C. Marble, N. Torres, and A. Chandler. 2019b. Fertilizer placement affects growth and reproduction of three common weed species in pine bark-based soilless nursery substrates. Weed Sci. 67:682-688

Schuster, R.M. 1966. The Hepaticae and Anthocerotae of North America: East of the hundredth meridian. Vol. 1. Columbia University Press, New York, NY.

Shimamura, M. 2015. Marchantia polymorpha: Taxonomy, phylogeny and morphology of a model system. Plant Cell Physiol. 57:230-256.

Smith, T. 2007. Cleaning and disinfecting the greenhouse. 12 Apr. 2020. <https://ag. umass.edu/greenhouse-floriculture/factsheets/cleaning-disinfecting-greenhouse $>$.
Smith, T. 2019. Managing weeds in and around the greenhouse. 12 Apr. 2020. <https://ag.umass.edu/greenhousefloriculture/fact-sheets/managingweeds-in-around-greenhouse $>$.

Soderstrom, L., A. Hagborg, M. von Konrat, S . Bartholomew-Began, D. Bell, L. Briscoe, E. Brown, D.C. Cargill, D.P. Costa, B.J. Crandal-Stotler, E.D. Cooper, G. Dauphin, J.J. Engel, D.G. Feldberg, S.R. Gradstein, X. He, J. Heinrichs, J. Hentschel, A.L. Ilkiu-Gorges, T. Katagiri, N.A. Konstantinova, J. Larraín, D.G. Long, M. Nebel, T. Pócs, F. Puche, E. Reiner-Drehwald, M.A.M. Renner, A. Sass-Gyarmati, A. Schafer-Verwimp, J.G.S. Moragues, R.E. Stotler, P. Sukkharak, B.M. Thiers, J. Uribe, J. Váňa, J.C. Villarreal, M. Wigginton, L. Zhang, and R.L. Zhu. 2016. World checklist of hornworts and liverworts. PhytoKeys 59:1-828.

Stamps, R.H. and A.L. Chandler. 2004. Eradication of liverwort from a soilless growing medium. HortScience 39:882.

Svenson, S.E. 1997. Controlling liverworts and mosses in nursery production. Comb. Proc. Intl. Plant Prop. Soc. 47:414-422.

Svenson, S.E. 1998. Suppression of liverwort growth in containers using irrigation, mulches, fertilizers and herbicides. Proc. Southern Nursery Assn. Res. Conf. 43:396-398.
Svenson, S. and W. Deuel. 2000. Using quinoclamine and meadowfoam seed meal to control liverworts in containers. Proc. Southern Nursery Assn. Res. Conf. 45:391-393.

Svenson, S., J. Paxson, and K. Sanford. 2001. Composts and shading influence Marchantia infestations in container grown nursery crops. Proc. Southern Nursery Assn. Res. Conf. 46:431-433.

Terui, K. 1981. Growth and gemma-cup formation in relation to archegoniophore protrusion in Marchantia polymorpha L. Ann. Rep. Fac. Educ. Iwate Univ. 40:1928.

Varanasi, A., P.V. Vara Prasad, and M. Jugulam. 2016. Impact of climate change factors on weeds and herbicide efficacy. Adv. Agron. 135:107-146.

Von Konrat, M., A.J. Shaw, and K.S. Renzaglia. 2010. A special issue of Phytotaxa dedicated to bryophytes: The closest living relatives of early land plants. Phytotaxa 9:5-10

Voth, P.D. and K.C. Hamner. 1940. Responses of Marchantia polymorpha to nutrient supply and photoperiod. Bot. Gaz. 102:169-205

Waltz, A.L., A.R. Martin, F.W. Roeth, and J.L. Lindquist. 2004. Glyphosate efficacy on velvetleaf varies with application time of day. Weed Technol. 18:931-939. 